International Journal of Management Science

and Business Administration

Volume 1, Issue 2, January 2015, Pages 20-32

\title{
Sustainable Supply Chain Management through Enterprise Resource Planning (ERP): a Model of Sustainable Computing
}

\author{
Broto Rauth Bhardwaj \\ Entrepreneurship \& Innovation Research Cell, Bharati Vidyapeeth University, \\ Institute of Management and Research, New Delhi, India \\ Corresponding author (e-mail): brotobhardwaj@gmail.com
}

\begin{abstract}
Green supply chain management (GSCM) is a driver of sustainable strategy. This topic is becoming increasingly important for both academia and industry. With the increasing demand for reducing carbon foot prints, there is a need to study the drivers of sustainable development. There is also need for developing the sustainability model. Using resource based theory (RBT) the present model for sustainable strategy has been developed. On the basis of data collected, the key drivers of sustainability were developed. We used regression and correlation analysis for developing the final model. The study findings suggest that the drivers of GSCM are the environmental policy and the green human resource management (GHRM). This can be done by providing training for adopting sustainability practices. Besides this, another key driver is the sustainability criteria in supplier selection which was found to be enhancing the outcomes of sustainability. The model has practical and theoretical value as it proposes that management support for implementing the sustainability strategy in the organization is essential. The study also guides the managers for implementing sustainable supply chain management practices in the organization.
\end{abstract}

Key words: Supply chain management, Computing, Enterprise, Growing sustainability

\section{Introduction}

The eco-friendly strategy has become a competitive strategy for the companies to survive in the emerging markets such as India. Study warned that if not confronted, climate change had the potential to contribute to conflicts and wars over diminishing resources such as food and water. By 
2050, the combined GDP of the emerging economies will be more than 50 per cent of the total GDP of the world. This would not be achieved without leaving carbon foot prints in the world. Moreover, Nidumolu, Prahalad, and Rangaswami (2009) found that the quest for sustainability can lead to organizational and technological innovations that can yield both top-line and bottom-line returns for companies. Hollos, Blome, and Foerstl (2012) examined the implications of sustainable supplier co-operation and studied the influence of supplier co-operation on performance of the organization. The increasing importance of sustainable behavior in business has enhanced its impact on supply chain management. Firms foster sustainability in their supplier base in reaction to growing sustainability requirements in various ways, including sustainable supplier co-operation. Knowledge about the effects of sustainable supplier co-operation on firm performance is limited; therefore, this study tests antecedents and implications of sustainable supplier co-operation according to the triple bottom line (Gavronski, Klassen, Vachon and Machado do Nascimento, 2012). A survey of Western European firms reveals that sustainable supplier co-operation has generally positive effects on firm performance across social, green and economic dimensions. However, only green practices have positive significant effects on economic performance, not social practices (e.g., child labour rules). Similarly, Gavronski, Klassen, Vachon, Nascimento and Luis Felipe proposed that manufacturing's choice of environmental technologies is expected to be partly driven by the organizational context and receptivity to new ideas and innovation (Gavronski, Klassen, Vachon and Machado do Nascimento, 2012).

The present study makes three significant contributions. First, it explains the role of environment policy for enhancing the sustainability strategy on the supply chain management. Second, it refined and validated scales that capture organizational processes within operations which can enhance adoption of sustainability practices among suppliers. Finally, this research highlighted the important role that plant-level social climate has on fostering a greater emphasis on pollution prevention. The managerial implications of this research are twofold.

\section{Literature review}

Zhu and Sarkis (2004) suggest that GSCM practices consist of four major dimensions: internal environmental management, external environmental management, investment recovery, and eco design. Internal environmental management includes commitment of GSCM by senior managers, support for GSCM by mid-level managers, cross-functional cooperation for environmental improvements, total quality environmental management, environmental compliance and auditing programs ISO 14001 certification, and environmental management systems. The external environmental management includes GSCM practices, providing design specification to suppliers that include environmental requirements for purchased item, cooperation with suppliers for environmental objectives, environmental audit for suppliers' internal management, suppliers' ISO14000 certification, second-tier supplier environmentally friendly practice evaluation, cooperation with customer for eco-design, cooperation with customers for cleaner production, and cooperation with customers for green packaging.

Investment recovery includes investment recovery (sale) of excess inventories/materials, sale of

21

ISSN 1849-5664 (online) $\quad$ http://researchleap.com/category/international-journal-of-management-science-and-business-administration ISSN 1849-5419 (print) International Journal of Management Science And Business Administration Vol 1. No 2. January 2015., pp. 20-32 
scrap and used materials, and sale of excess capital equipment. Eco-design includes design of products for reduced consumption of material/energy, design of products for reuse, recycle, recovery of material, component parts, design of products to avoid or reduce use of hazardous, and products and/or their manufacturing process (Dey, LaGuardia, and Srinivasan, 2011). Vickery et al. (1999) defined five supply chain flexibilities based on previous operations literature in order to look at supply chain uncertainty problems. The author described the flexibility type including product flexibility, volume flexibility, new product flexibility, distribution flexibility and responsiveness flexibility (Yavuz Acar, and Sukran Kadipasaoglu, 2012). Product flexibility is defined as the ability to customize product to meet specific customer demand. Volume flexibility is the ability to adjust capacity to meet changes in customer quantities. New product flexibility is the ability to launch new or revised products.

Over the past decade, SCM has played an important role for organizations' success and subsequently the green supply chain (GSC) has emerged as an important component of the environmental and supply chain strategies of a large number of companies (Sam; Kleindorfer, de Miera Polvorinos, Saenz, 2012). Although the term "environment" or "greening" has an ambiguous meaning in various fields, the term indicates not only harmonizing corporate environmental performance with stockholders' expectations but also developing a critical new source of competitive advantage in terms of management perspective (Gupta, 1994). According to Gupta (1995), environmental management relieves environmental destruction and improves environmental performance by institutionalizing various greening practices and initiating new measures and developing technologies, processes and products (Yann, Asma, Zied, Yves, 2012).

Some studies focused on external environmental factors such as customers and suppliers (Bilbao, Carrano, Hewitt, Thorn, 2011). To improve their own environmental supply chain performance, organizations need the interactions with the government, suppliers, customers, and even competitors (Carter and Ellram, 1998). Cooperation with suppliers and customers has become extremely critical for the organizations' to close the supply chain loop (Zhu et al., 2008). GSCM practices are divided into four major dimensions: internal environmental management, external environmental management, investment recovery, and eco design (Zhu and Sarkis, 2004; Biddle, 2011). Moreover, Jayaraman, Singh and Anandnarayan (2012) suggest that adopting an environmental perspective on operations can lead to improved operations. The study further suggests that any operational system that has minimized inefficiencies is also more environmentally sustainable. The study compared green manufacturing techniques in place in two world-class, ISO 14001-certified paint manufacturing firms in India to ascertain the cost benefits that these firms enjoy due to green manufacturing and recycling.

On the contrary, Bouchery, Ghaffari, Jemai and Dallery (2012) identified the need of study of quantitative models in operations management. Their study contributes by revisiting classical inventory methods taking sustainability concerns into account. They designed sustainable order quantity model which can help decision makers to quickly identify the best option among these solutions. Similarly, Dinwoodie, Tuck, Knowles, Benhin and Sansom (2012) designed a framework to facilitate environmental management applies business process principles to identify relevant inputs,

22

ISSN 1849-5664 (online) $\quad$ http://researchleap.com/category/international-journal-of-management-science-and-business-administration ISSN 1849-5419 (print) International Journal of Management Science And Business Administration Vol 1. No 2. January 2015., pp. 20-32 
processes and outputs. The study further suggests that simplification and optimization phases of business process re-engineering can be tapped by business strategists for enhancing adoption of sustainable practices (Acar and Kadipasaoglu, 2012). Tang and Zhou (2012) suggest the correlation between profitability and sustainability. However, the balance can only be maintained in the long run if the firm can take a holistic approach to sustain the financial flow (profit), resource flow (planet) and development flow (people) for the entire ecosystem comprising poor producers in emerging/developing markets, global supply chain partners, consumers in developed countries, and the planet (Blandine, Angappa and Spalanzani, 2012; Rastogi, Siddique, Kumar and Singh, 2013).

Likewise, Sarkis (2012) studied the social issues such as sustainability, poverty alleviation, health care management, philanthropic activities, humanitarian aid, and education can all benefit from modeling efforts from operations management and production economics researchers (Goel and Jindal, 2013). The author defined compassionate operations and included the culmination of major natural and man-made crises, increased environmental concerns, and increased globalization and knowledge, comes a wider awareness of social problems that need to be addressed (Walsh and Dowding, 2012; Warren, 2012).

Dey, LaGuardia and Srinivasan (2011) examined the current state of sustainability efforts within the field of supply chain management, more specifically supply chain logistics operations, and to identify opportunities and provide recommendations for firms to follow sustainable operations. The study shows that for firms to implement a sustainability strategy in their supply chain operations, the logistics function needs to play a prominent role because of the magnitude of costs involved and the opportunity to identify and eliminate inefficiencies and reduce the carbon footprint (Dey, LaGuardia, and Srinivasan, 2011). Huang, Yan and Qiu (2009) suggested the concept of closed-loop supply chain (CLSC) management to meet the current environmental challenges and sustainable development. The study suggests that mainly three challenges are there for SCM namely, (1) uncertainty of time-delay in re-manufacturing and returns, (2) uncertainty of system cost parameters, (3) uncertainty of customers' demand disturbances. The study was based on operations of scrap supply chain in the Chinese steel industry (Zhang, Joglekar, Verma, 2012). Ageron, Gunasekaran and Spalanzani (2012) study suggests that sustainability research on supply management has received limited attention. Similarly, Schoenherr (2012) investigated the influence of sustainable business development on manufacturing plant operations focusing on the environmental component. Specifically, on the basis of resource-based view of the firm, the authors have hypothesized the impact of environmental management on plant performance. Zhang, Joglekar and Verma (2012) created a benchmark for the environmental sustainability (ES) initiatives by constructing a cost-based resource efficiency measure for ES from reported financial data. This approach linked the environmental and economic performance outcomes by extracting information from resource related expenses normalized by RevPAR (revenue per available room). Kornfeld and Kara (2011) suggest that manufacturing organizations must routinely deliver efficiencies in order to compete. However, their ability to realize sustainable competitive advantage is hampered by the lack of sustainable objective. Sanchez-Rodrigues, Potter and Naim (2010) indicate that the main drivers impacting the sustainability of transport operations are delays, variable demand/poor information, delivery constraints and insufficient supply chain integration. Bilbao, Carrano, Hewitt 
and Thorn (2011) framed model associated with the management of pallets throughout the entire life cycle, from materials to manufacturing, use, transportation to end-of-life disposal.

Therefore we propose the following hypothesis:

Hypothesis 1: Designing environmental policy influences sustainable supply chain management positively.

Walsh and Dowding (2012) examined Coca Cola's corporate sustainability strategy in terms of the sourcing, usage and replenishment of water used in its beverage production. On the basis of value chain analysis of water, the major economic, social and environmental issues surrounding sustainable water management were analyzed. Coca-Cola's water stewardship initiatives - from rainwater harvesting in Africa to reducing the water used in its operations - demonstrate sustainable water leadership can serve as a solution for water stressed regions of the world. Pinheiro, Rendeiro, Pinho and Macedo (2011) presented a case study of the electrification of a riparian community in the State of Pará, Brazil, with electrification facilities through a small biomass-based power plant, directly firing residues produced by the local economic activity.

Warren (2012) proposed that the scenario analysis can be very critical for analyzing possible future events of sales and operations planning (S\&OP). The study conducted by researcher shows that proactive approach in sustainable operations helps a business to decide on environmental issues leadership in product differentiation (Biddle, 2011. Warren (2012) measured the environmental performance issues in three ways, namely, improving its culture and operations, impacting its suppliers, and starting renewable-energy development. The study also describes the center of strategy and top managers' commitment by joining teams that go out to the field for auditing environmental, health,, and safety compliance. Brazilian suppliers aim to make themselves best in greenest efforts. The company measures and monitors their environmental performance. It aims to become a world leader in biofuel by building a R\&D network.

Therefore, we propose the hypothesis:

Hypothesis 2: Implementing environmental criteria to select suppliers influences the sustainable supply chain management positively.

The following methodology was adopted to test the hypotheses.

\section{A. Methodology}

This paper included the respondents from both manufacturing and service firm located in India. The sampling companies which have adopted sustainable practices were included in the research. Questionnaires were emailed to top managers of manufacturing and service industry firms. The valid mailing was 528 surveys, from which 326 responses were received. We used only 227 responses. The response rate was approximately $23.51 \%$. Aaker, Kumar, Day (2001) stated that the response rate for the mail survey should not be less than $20 \%$. Non-response bias was also

24

ISSN 1849-5664 (online) $\quad$ http://researchleap.com/category/international-journal-of-management-science-and-business-administration ISSN 1849-5419 (print) International Journal of Management Science And Business Administration Vol 1. No 2. January 2015., pp. 20-32 
investigated using Chi-square (Armstrong and Overton, 1977). Therefore, for the study, the response rate is acceptable. Factor analysis has a potential to improve the component loadings. It was used to test the validity of data in the questionnaire. The items were used to measure construct that was extracted to be the only principal component. Table 1 shows factor loadings greater than 0.40 were used. These are statistically significant (Nunnally and Berstein, 1994). The scales of the variables were measured also produced internally consistent results. Thus, these measures were found appropriate for analysis. This is because they expressed accepted reliability and validity measures.

\section{B. Variables}

All the variables were measured from the survey. Researchers used a 5-point scale (strongly disagree (1) to strongly agree (5)) to measure all constructs. Sustainable strategy variables were adapted from Lai, Cheng and Tang (2010). These measures assessed the degree of practice, processes, and decision-making activities which help to implement the sustainable strategy. Measures of operation flexibility were taken for both centrality and complexity (Adamides et al., (2005). Firm size was included as a control measure. This is because small firms have a disadvantage with respect to their resource allocation and advantages compared with firm size. Firm size is operationalized as a variable, with a value of zero assigned to firms (less than 100 employees) and value assigned to big firms (100 or more employees) (Kirchhoff, 1994).

The reliability was evaluated by Cronbach's Alpha coefficient. In the study reliability, Cronbach's alpha coefficients are greater than 0.60 (Nunnally, 1967). Table 1 provides an alpha coefficient higher than 0.60 and Cronbach's alpha coefficient of constructs have values ranging from 0.61 to 0.86 the coefficient for performance and the coefficient for brand association. Therefore, internal consistency can be used in this study which is good for all constructs.

\section{Results and discussion}

Table 1 shows the correlation coefficients for all variables. Variance factors (VIFs) were used to check issues relating to multicollinearity, with non-orthogonality in independent variables. The variance range from 1.03 to 2.82 well (Neter, Wasserman and Kutner, 1995). Hence, there is no multicollinearity issues encountered in this study.

25

ISSN 1849-5664 (online) $\quad$ http://researchleap.com/category/international-journal-of-management-science-and-business-administration ISSN 1849-5419 (print) International Journal of Management Science And Business Administration Vol 1. No 2. January 2015., pp. 20-32 
Broto Rauth Bhardwaj

Sustainable Supply Chain Management Through Enterprise Resource Planning (ERP): a Model of Sustainable Computing

\begin{tabular}{|c|c|c|c|c|c|c|c|c|}
\hline & & $\begin{array}{l}\text { Explicit } \\
\text { definition } \\
\text { of } \\
\text { environme } \\
\text { ntal policy }\end{array}$ & $\begin{array}{l}\text { Clear } \\
\text { objectives } \\
\text { and long } \\
\text { term } \\
\text { environme } \\
\text { ntal plans }\end{array}$ & $\begin{array}{l}\text { Sponsorin } \\
\mathrm{g} \quad \text { of } \\
\text { environme } \\
\text { ntal } \\
\text { events/col } \\
\text { laboration } \\
\text { with } \\
\text { ecological } \\
\text { organizati } \\
\text { on }\end{array}$ & $\begin{array}{l}\text { Disposabl } \\
\text { e disposal } \\
\text { of waste } \\
\text { and } \\
\text { residues } \\
\text { (separatio } \\
\text { n and } \\
\text { preparati } \\
\text { on) }\end{array}$ & $\begin{array}{l}\text { Environme } \\
\text { ntal } \\
\text { criteria in } \\
\text { supplier } \\
\text { selection }\end{array}$ & $\begin{array}{l}\text { Shipments } \\
\text { consolidati } \\
\text { on }\end{array}$ & $\begin{array}{l}\text { Supplier } \\
\text { and NGO } \\
\text { cooperati } \\
\text { on in } \\
\text { carbon } \\
\text { labeling }\end{array}$ \\
\hline $\begin{array}{l}\text { Explicit definition } \\
\text { of environmental } \\
\text { policy }\end{array}$ & $\begin{array}{l}\text { Pearson } \\
\text { Correlatio } \\
\mathrm{n}\end{array}$ & 1 & $.468\left(^{* *}\right)$ & .279 & $.336\left(^{*}\right)$ & .172 & .034 & -.280 \\
\hline $\begin{array}{l}\text { clear objectives } \\
\text { and long term } \\
\text { environmental } \\
\text { plans }\end{array}$ & $\begin{array}{l}\text { Pearson } \\
\text { Correlatio } \\
n\end{array}$ & $.468\left(^{* *}\right)$ & 1 & .160 & $.652\left(^{* *}\right)$ & .115 & .042 & -.149 \\
\hline $\begin{array}{l}\text { sponsoring of } \\
\text { environmental } \\
\text { events/collaboratio } \\
n \text { with ecological } \\
\text { organization }\end{array}$ & $\begin{array}{l}\text { Pearson } \\
\text { Correlatio } \\
\mathrm{n}\end{array}$ & .279 & .160 & 1 & .104 & -.043 & -.051 & .021 \\
\hline $\begin{array}{l}\text { disposable disposal } \\
\text { of waste and } \\
\text { residues } \\
\text { (separation and } \\
\text { preparation) } \\
\end{array}$ & $\begin{array}{l}\text { Pearson } \\
\text { Correlatio } \\
n\end{array}$ & $.336\left(^{*}\right)$ & $.652\left(^{* *}\right)$ & .104 & 1 & -.130 & -.061 & -.044 \\
\hline $\begin{array}{l}\text { environmental } \\
\text { criteria in supplier } \\
\text { selection }\end{array}$ & $\begin{array}{l}\text { Pearson } \\
\text { Correlatio } \\
\mathrm{n}\end{array}$ & .172 & .115 & -.043 & -.130 & 1 & $.844(* *)$ & .298 \\
\hline $\begin{array}{l}\text { shipments } \\
\text { consolidation }\end{array}$ & $\begin{array}{l}\text { Pearson } \\
\text { Correlatio } \\
\mathrm{n} \\
\end{array}$ & .034 & .042 & -.051 & -.061 & $.844\left({ }^{* *}\right)$ & 1 & $.422\left(^{* *}\right)$ \\
\hline $\begin{array}{l}\text { supplier and NGO } \\
\text { cooperation in } \\
\text { carbon labeling }\end{array}$ & $\begin{array}{l}\text { Pearson } \\
\text { Correlatio } \\
\mathrm{n}\end{array}$ & -.280 & -.149 & .021 & -.044 & .298 & $.422\left(^{* *}\right)$ & 1 \\
\hline
\end{tabular}

Table 3- 1: Environmental policy leading to better implementation of sustainability strategy

Table 3-1 shows that long term environmental plans and having clear objectives influence the disposable of waste and residues (separation and preparation) by recycling the waste $(0.652)$. Moreover, the study also shows that there is a significant correlation between environmental criteria in supplier selection and the shipments consolidation (0.844). Therefore, study shows that designing the sustainability policy and including the green supply chain mission will enhance the firm's competitiveness and performance. According to sustainability strategy as organizational process that contributes to firm performance (Zhang, Joglekar and Verma, 2012); Bhardwaj and Lai (2012) argue that green technology (technopreneurship) enhances the performance of the organization. Surprisingly, with green supply chain management, the firm performance is enhanced 
in terms of enhancing the image of the company in the eyes of the customer which gives boost to the sales. A finding inconsistent to Zeithaml and Bitner, (2003) argue that sustainability brings back the repeat customers and thus increases firm growth.

\subsection{Reliability Assessment}

Internal consistency reliability measures were assessed on the factor structures derived from both analyses reported above, using the Chronbach's procedure available in the SPSS statistical package. Those variables have been retained for which the values of Chronbach alpha are more than 0.5 (Table 3-2).

\begin{tabular}{|l|l|}
\hline Variables & Cronbach Alpha $\alpha$ \\
\hline Green policy & \\
\hline $\begin{array}{l}\text { Green technology } \\
\text { Green human resource } \\
\text { management }\end{array}$ & 0.76 \\
\hline Green supply chain management & 0.79 \\
\hline Green production flexibility & 0.60 \\
\hline
\end{tabular}

Table 3-2: Reliability Assessment

\begin{tabular}{|l|l|l|l|l|}
\hline Model & $\mathrm{R}$ & $\begin{array}{l}\mathrm{R} \\
\text { Square }\end{array}$ & $\begin{array}{l}\text { Adjusted } \\
\text { Square }\end{array}$ & $\mathrm{R}$ \\
\hline 1 & Std. Error of the Estimate \\
\hline 2 & $.566^{\mathrm{a}}$ & .320 & .303 & 1.207 \\
\hline $\begin{array}{l}\text { a. Predictors: (Constant), clear objectives and long term environmental plans } \\
\text { b. Predictors: (Constant), clear objectives and long term environmental plans, natural } \\
\text { environment training programs for managers and employees } \\
\text { c. Dependent Variable: preference for green products in purchasing }\end{array}$ \\
\end{tabular}

Table 3-3: Model summary of regression analysis of clear objectives and long term environmental plans to enhance the employee's adoption of sustainability strategy 
Table 3-3 suggests that having clear objectives and long term environmental plans also influences the natural environment training programs for managers and employees which in turn enhance the performance of sustainability strategy. Moreover, the first major predictor of sustainability is designing environmental policy (EP) as shown in Table 3-3. The other predictors are natural environment training programs for managers and employees. All these variables together explain 41.5 per cent of the variance in sustainability; the rest is dependent on other variables and spurious variables not included in the model. The corresponding ANOVA values for the regression model are shown in Table 3-4 indicating validation at 99 per cent confidence level. The coefficient summary as shown in Table 3-5 gives Beta values of environmental policy (EP), training the employees on sustainability (TR) and sustainability outcomes measured as customer preference for green products (GP), which are fairly representative of their impact on sustainability. Thus, environmental policy (EP) is emerging as a major influence variable for sustainability.

\begin{tabular}{|c|c|c|c|c|c|c|}
\hline \multicolumn{2}{|c|}{ Model } & \multirow{2}{*}{\begin{tabular}{|l|}
$\begin{array}{l}\text { Sum of } \\
\text { Squares }\end{array}$ \\
27.392 \\
\end{tabular}} & \multirow{2}{*}{$\frac{\mathrm{df}}{1}$} & \multirow{2}{*}{\begin{tabular}{|l} 
Mean Square \\
27.392
\end{tabular}} & $\mathrm{~F}$ & \multirow{2}{*}{$\frac{\text { Sig. }}{.000^{\mathrm{a}}}$} \\
\hline 1 & Regression & & & & 18.817 & \\
\hline & Residual & 58.227 & 40 & 1.456 & & \\
\hline & Total & 85.619 & 41 & & & \\
\hline \multirow[t]{3}{*}{2} & Regression & 37.955 & 2 & 18.977 & 15.528 & $.000^{b}$ \\
\hline & Residual & 47.664 & 39 & 1.222 & & \\
\hline & Total & 85.619 & 41 & & & \\
\hline
\end{tabular}

a. Predictors: (Constant), clear objectives and long term environmental plans

b. Predictors: (Constant), clear objectives and long term environmental plans, natural environment training programs for managers and employees

c. Dependent Variable: preference for green products in purchasing

Table 3-4: ANOVA for Sustainability as Dependent Variable

Table 3-4 shows the ANOVA values for sustainable supply chain management. On the basis of the regression analysis, the sustainability model has been developed (Figure 3-1). The model shows the drivers of sustainability with the beta values. 


\section{Macro Variables}

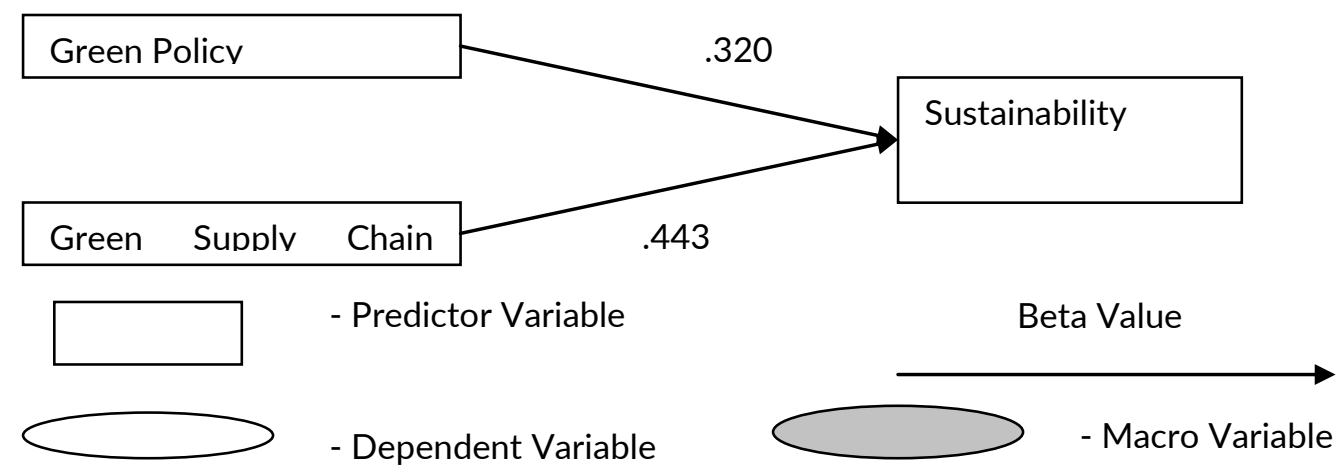

Figure 3-1: Validated Model for Macro Variables as Predictors of Sustainability

\subsection{Correlation Analysis}

All eight macro variables of organizational antecedents and sustainability Outcome variable have been correlated using the Pearson correlation test for the full sample of 281 responses. The results obtained by the test are shown in Table 3-5. The statistical significance of correlation is indicated with single and double asterisks marks for probability levels of less than 0.05 and less than 0.01 respectively.

\begin{tabular}{|l|l|l|l|l|}
\hline & GP & GHRM & GT & SO \\
\hline GP & 1 & & & \\
\hline GHRM & $.367^{* *}$ & 1 & & \\
\hline GT & $.454^{* *}$ & $.557^{* *}$ & 1 & \\
\hline SO & $.501^{* *}$ & $.566^{* *}$ & $.683^{* *}$ & 1 \\
\hline
\end{tabular}

** Correlation is significant at the 0.01 level (2-tailed)

Table 3-5: Correlation of Macro Variables for the Total Sample

There is a significant correlation among the macro variables Green Policy (GT), Green human resource management (GHRM), Green technology (GT) and Sustainability Outcomes (SO). The highest level of correlation is between Sustainability Outcomes and Green technology (0.683) at 99 per cent confidence level. The explanation for that might be that in most of the organizations, desired Sustainability Outcomes is not possible without proper adopting proper technology (Bhardwaj, Bhatnagar, Gupta, 2012). 


\section{Contributions}

The objective of the study was to show the importance of green supply chain management for the betterment of people, planet and profit. Result show that the sustainability strategy will lead to better performances, particularly the challenging and competitive environment. This study reveals that it is critical to have sustainable policy for better firm competitiveness. This result is consistent with prior result published by Hamel and Prahalad (1991). Entrepreneurial activities involve creating new products leading needs of customers. This implies that the organization must be ready to change as quickly as changing needs of customer. This leads us to propose that the innovative organizations will perceive that the organization is ready to change. However, correlation coefficient between green supply chain management (GSCM) and green policy provide significant positive relationship. This result confirms the hypothesis. Beside, future researchers need to study this relationship from other GSCM point of view. It links strategic management variables and organization behavior construct. Researcher must search literature from both disciplines and relevant disciplines that prepare the completely understanding them.

\section{Conclusion}

The paper shows the role of environmental policy in enhancing the adoption of sustainable strategy. Although the study provides useful insights into the role of environmental policy on firm's competitiveness some certain limitations should be acknowledged. First, the study used research reports to measure the constructs. A different approach would have been to combine information from multiple respondents (Kumar et al., 1993). Second, the research design limits the extent to which inferences can be made. Finally, research in industries other than service and manufacturing sectors is required. The pace of strategic change in some industries might differ from the manufacturing sectors that we studied.

\section{References}

- Aaker, D. A., Kumar, V., \& George, S. Day. 2001. Marketing research, 7

- Ageron, Blandine; Gunasekaran, Angappa; Spalanzani (2012) Sustainable supply management: An empirical study, Alain International Journal of Production Economics, Vol. 140 Issue 1, p168-182.

- Asoke Dey, Paul LaGuardia, Mahesh Srinivasan, (2011) "Building sustainability in logistics operations: a research agenda", Management Research Review, Vol. 34 Iss: 11, pp.1237 1259.

- Aflaki, Sam; Kleindorfer, Paul R.; de Miera Polvorinos, Victor Saenz (2012) Finding and Implementing Energy Efficiency Projects in Industrial Facilities, INSEAD Working Papers Collection, Issue 60, proceeding p1-27.

- Armstrong, J. S., \& Overton, T. S. (1977). Estimating nonresponse bias in mail surveys. Journal of marketing research, 396-402.

- Bouchery, Yann; Ghaffari, Asma; Jemai, Zied; Dallery, Yves (2012) Including sustainability criteria into inventory models, European Journal of Operational Research, Vol. 222 Issue 2,

30

ISSN 1849-5664 (online) $\quad$ http://researchleap.com/category/international-journal-of-management-science-and-business-administration ISSN 1849-5419 (print) International Journal of Management Science And Business Administration Vol 1. No 2. January 2015., pp. 20-32 
p229-240.

- Bilbao, A. Mazeika; Carrano, A.L.; Hewitt, M.; Thorn, B.K. (2011) On the environmental impacts of pallet management operations, Management Research Review, Vol. 34 Issue 11, p1222-1236.

- Biddle, Ian (2011) Operations Management for a Sustainable Future, BusiDate, Vol. 19 Issue 1, p2-5.

- Dey, A., LaGuardia, P., \& Srinivasan, M. (2011). Building sustainability in logistics operations: a research agenda. Management Research Review, 34(11), 1237-1259.

- Dinwoodie, J., Tuck, S., Knowles, H., Benhin, J., \& Sansom, M. (2012). Sustainable development of maritime operations in ports. Business Strategy and the Environment, 21(2), 111-126.

- Gavronski, I., Klassen, R. D., Vachon, S., \& Nascimento, L. F. M. D. (2012). A learning and knowledge approach to sustainable operations. International Journal of Production Economics, 140(1), 183-192.

- Grama, A., Gupta, A., \& Karypis, G. (1994). Introduction to parallel computing: design and analysis of algorithms. Redwood City, CA: Benjamin/Cummings Publishing Company.

- Hruschka, E. R., Campello, R. J. G. B., Freitas, A. A., \& De Carvalho, A. P. L. F. (2009). A survey of evolutionary algorithms for clustering. Systems, Man, and Cybernetics, Part C: Applications and Reviews, IEEE Transactions on, 39(2), 133-155.

- Hollos, D., Blome, C., \& Foerstl, K. (2012). Does sustainable supplier co-operation affect performance? Examining implications for the triple bottom line. International Journal of Production Research, 50(11), 2968-2986.

- Kornfeld, B. J., \& Kara, S. (2011). Project portfolio selection in continuous improvement. International Journal of Operations \& Production Management, 31(10), 1071-1088.

- Neha Goel and Aashi Jindal (2013) Implementation of Cost Effective Solution for eGovernance Through APUS (Aadhar Card, PPP, Underprivileged, SMS) Proceedings of the 7th National Conference; INDIACom-2013

- Nidumolu, R., Prahalad, C. K., \& Rangaswami, M. R. (2009). Why sustainability is now the key driver of innovation. Harvard business review, 87(9), 56-64.

- Pinheiro, G., Rendeiro, G., Pinho, J., \& Macedo, E. (2011). Rural electrification for isolated consumers: Sustainable management model based on residue biomass. Energy Policy, 39(10), 6211-6219.

- $\quad$ Rohit Rastogi, Mohammed Ishaq Siddique, Ankit Kumar and Gautam Kumar Singh (2013) Role of Information Technology in Disaster Management, Proceedings of the 7th National Conference; INDIACom-2013

- Schoenherr, T. (2012). The role of environmental management in sustainable business development: a multi-country investigation. International Journal of Production Economics, 140(1), 116-128.

- $\quad$ Sanchez-Rodrigues, V., Potter, A., \& Naim, M. M. (2010). The impact of logistics uncertainty on sustainable transport operations. International Journal of Physical Distribution \& Logistics Management, 40(1/2), 61-83.

- Walsh, Heather; Dowding, Timothy J. (2012) Sustainability and the Coca-Cola Company: The Global Water Crisis and Coca-Cola's Business Case for Water Stewardship, 
International Journal of Business Insights \& Transformation, Special Issue, Vol. 4, p106-118.

- Warren, Lillian (2012) Scenario Analysis for S\&OP, Journal of Business Forecasting, Vol. 31 Issue 1, p32-35.

- Yavuz Acar, and Sukran Kadipasaoglu (2012) An Empirical Study of Volume and Storage Flexibility in a Global Supply Chain, Proceedings paper.

- Zeithaml, V. A., Bitner, M. J., \& Gremler, D. D. (2006). Services marketing: Integrating customer focus across the firm.

- Zhang, Jie J.; Joglekar, Nitin R.; Verma, Rohit (2012) Exploring Resource Efficiency Benchmarks for Environmental Sustainability in Hotels, Cornell Hospitality Quarterly, Vol. 53 Issue 3, p229-241.

- Zhu, Q., Sarkis, J., \& Geng, Y. (2005). Green supply chain management in China: pressures, practices and performance. International Journal of Operations \& Production Management, 25(5), 449-468.

- Zsidisin, G. A., Ellram, L. M., Carter, J. R., \& Cavinato, J. L. (2004). An analysis of supply risk assessment techniques. International Journal of Physical Distribution \& Logistics Management, 34(5), 397-413. 